\title{
PROGRESIFITAS FORMULASI HUKUM EKONOMI SYARIAH DI INDONESIA
}

\author{
Mohamad Nur Yasin \\ Fakultas Syariah UIN Maulana Malik Ibrahim Malang \\ yasinm.nuryasin@yahoo.co.id
}

\begin{abstract}
The chronological journey of sharia economic law begin from a level of normativeindicative consisting Quranic verses until to be indicate that there is progressive massively. Each phase appearing indicate the axistance of intensive dialog of civilization and cultur between the law of syariah economic and the law of conventional economic. The intensive-interactive dialog appears a product of new thought reconstructively basing logic of discover (logika temuan baru) and not logic of repetition (logika mengulang-ngulang). In the middle of interconnection of economic, social, politic, and law, the writer formulates four conceptual phases pharadigmatically representing long journey of syariah economic law begin from syariah era, fiqh era, qânûn era, and qadla era.

Kronologi perjalanan hukum ekonomi syariah mulai dari tataran normatif-indikatif berupa teks-teks al-Quran sampai munculnya berbagai regulasi ekonomi syariah menunjukkan bahwa terjadinya progresifitas secara masif. Setiap fase yang muncul menunjukkan intensitas dialog peradaban dan budaya antara hukum ekonomi syariah dengan ekonomi konvensional. Dialog intensif-interaktif tersebut memunculkan produk pemikiran baru yang rekonstruktif dengan tetap mengacu pada logika temuan baru (logic of discovery) dan bukan logika mengulang-ulang (logic of repetition). Di tengah interkoneksi fenomena ekonomi, sosial, politik, dan hukum, penulis merumuskan empat fase konseptual paradigmatik yang merepresentasikan perjalanan panjang progresifitas hukum ekonomi syariah mulai era syariah, era figh, era qânûn, dan era qadla.
\end{abstract}

Kata Kunci: Hukum ekonomi syariah, fiqh, qânûn, qadla

Secara normatif, Islam membolehkan perdagangan yang dilakukan secara konsensual. ${ }^{1}$ Konsensual hampir selalu muncul jika terdapat keseimbangan antara hak dan kewajiban yang dimiliki masing-masing pihak. Setiap pihak harus menjamin dirinya mampu bekerja. Menurut Mahmud Syalthout, Islam agama kerja (dîn al-amâliyah $)^{2}{ }^{2}$ Pada prinsipnya, setiap profesi dengan keahliannya masing-masing (advokat, notaris, hakim, jaksa, dosen, bangkir, polisi, bisnisman, dan sebagainya) adalah melakukan jual beli atau berdagang. Rasulullah Muhammad Saw adalah figur pedagang ulet dan ulung, baik sebelum

\footnotetext{
${ }^{1}$ QS, an-Nisa: 29

2 Mahmud Syalthout, Al-Islam, Aqidah wa Syari'ah (Kairo: Darul Qalam, 1966), h. 258
}

maupun sesudah mendapat mandat sebagai Rasul. $^{3}$

Secara empirik faktual, Kementerian Keuangan India mempertimbangkan penawaran produk perbankan syariah melalui perusahaan keuangan nonbank di India. $^{4}$ Menurut_Dr. Terry Lacey, dosen ekonomi dari Manchester University, Inggris, kemampuan Inggris dalam mendukung perkembangan institusi keuangan syariah tidak lepas dari

3 Afzalurrahman, Muhammad Sebagai Seorang Pedagang (Jakarta: Yayasan Swarna Bhumi, 1997), h. 3

4 India Cari Solusi Penyaluran Produk Keuangan Syariah, Republika on line, 8 April 2010. http://www.republika.co.id/berita/bisnissyariah/berita/10/04/08/110177-india-cari-solusipenyaluran-produk-keuangan-syariah, diunduh 8 Desember 2014 
posisi Inggris sebagai pusat keuangan dunia. Inggris bertekad menjadi pusat kajian ekonomi syraiah terbesar di Eropa. ${ }^{5}$ Indonesia sebagai Negara dengan jumlah penduduk Muslim terbesar di dunia, memiliki potensi yang sangat besar untuk berperan secara maksimal dalam industri ekonomi syariah. Potensi kekayaan Indonesia sebagai backing asset transaksi syariah sangat besar didukung posisi Indonesia yang sangat strategis dalam menghubungkan dua pusat likuiditas keuangan dunia, yaitu kawasan Asia Timur (Jepang, Korea, China) dan kawasan Timur Tengah. ${ }^{6}$ Dengan demikian, perkembangan ekonomi syariah telah melintas batas negara dan melintas batas keyakinan agama. Hal ini tergambar dari eksistensi India sebagai negara yang mayoritas penduduknya beragama Hindu dan Inggris sebagai pusat gereja Katolik Anglo Saxon di dunia telah menerima, mengembangkan, dan bertekad menjadi pusat keuangan syariah di dunia.

Di Indonesia, ekonomi syariah tidak saja berkembang dalam bentuk booming lembagalembaga bisnis syariah secara masif, dinamisnya institusi pendidikan tinggi berbasis ekonomi syariah, tetapi juga dalam bentuk legeslasi ekonomi syariah dalam tata hukum nasional (ius constitutum) dengan terbitnya UU No. 3 Tahun 2006 tentang Perubahan atas UU No. 7 Tahun 1989 Tentang Peradilan Agama, UU No. 19 Tahun 2008 tentang Surat Berharga Syariah Negara, UU No. 21 Tahun 2008 tentang Perbankan Syariah, UU No. 48 Tahun 2009 tentang Kekuasaan Kehakiman, dan UU No. 50 Tahun 2009 Tentang Perubahan Kedua atas UU N 7 Tahun 1989 Tentang Peradilan Agama.

Kronologi perjalanan hukum ekonomi syariah mulai dari tataran normatif-indikatif berupa teks-teks al-Quran sampai terbitnya berbagai UU hukum ekonomi syariah menunjukkan bahwa terjadi progresifitas atau kemajuan secara cepat konsepsi teoritis paradigmatik formulasi hukum ekonomi syariah di Indonesia. Tiap tahapan memiliki

5 Terry Lacey, Growth of Islamic Banking and Finance in the United Kingdom, http://mifsifeui.wordpress.com/category/ekonomi-islam, diunduh 8 Desember 2014.

6 Lacey, Growth of Islamic Banking ...., diunduh 8 Desember 2014 karakteristik dan keunikan tersediri yang menggambarkan momentum, locus, tempus, dan situasi sosial ekonomi politik yang mengitarinya. Selain itu, setiap tahapan konsep menunjukkan tingkat intensitas dialog peradaban antara hukum ekonomi syariah di satu pihak dengan peradaban atau budaya konvensional di pihak lain. Dialog intensif interaktif antar dua budaya dan peradaban cenderung selalu memunculkan produk pemikiran baru yang rekonstruktif. Sehingga pengalaman dan tindakan yang berlaku di setiap era tergambar dalam setiap output interaksi tersebut. Menurut Clifford Geertz, agama merupakan institusi sosial, peribadatan merupakan aktifitas sosial dan kepercayaan merupakan kekuatan sosial. Sedangkan budaya adalah interpretasi tentang pengalaman dan tindakan manusia. $^{7}$

Hukum ekonomi syariah merupakan bagian penting dari hukum Islam. Menurut Muhammad Khudari Bek, ada enam fase perkembangan hukum Islam. Pertama, fase kerasulan Muhammad Saw. Kedua, fase sahabat senior sampai akhir masa Khulafaur Rasyidin. Ketiga, fase sahabat yunior, mulai dari permulaan Daulat Umayyah sampai akhir abad pertama hijriyah. Keempat, fase fiqh menjadi ilmu tersendiri, mulai awal abad kedua hijriyah sampai akhir abad ketiga hijriyah. Kelima, fase perbedaan mengenai masalah hukum di kalangan fuqaha, mulai awal abad keempat hijriyah sampai penakhlukan Abbasiah pada abad ketujuh hijriyah (1258 M). Keenam, fase taqlid, mulai dari kejatuhan Abbasiyah sampai sekarang. ${ }^{8}$ Fase-fase versi Khudari Bek dilanjutkan dan direvisi oleh Rifyal Ka'bah bahwa sekarang ini merupakan fase ketujuh. Fase ketujuh adalah fase kodifikasi dan kompilasi hukum Islam di berbagai negara serta maraknya ijtihad masalah kontemporer oleh berbagai lembaga fatwa untuk memperkaya hukum positif negara. ${ }^{9}$ Dari sisi yang tidak jauh berbeda, M. Atha' Mudzhar mengidentifikasi hasil ijtihad atau

${ }^{7}$ Clifford Geertz, The Interpretation of Cultures (New York: Basic Book, Inc., 1973), h. 5

8 Rifyal Ka'bah, Hukum Islam di Indonesia, Perspektif Muhammadiyah dan NU (Jakarta: Universitas Yarsi Press, 1999), h. 53

${ }^{9}$ Muhammad Khudari Bek, Tarikh Tasyri al-Islami (Beirut: Darul Fikr, 1988), h. 6 
produk pemikiran hukum Islam ada empat macam, yaitu fiqh, fatwa, qânûn (undangundang), dan qadla (putusan pengadilan). ${ }^{10}$

Rumusan Khudhari Bek, Rifyal Ka'bah, dan Atho' Mudzhar sangat urgen untuk ditindaklanjuti. Sebagai bagian dari rekonstruksi hukum ekonomi syariah, agar logika mengulang-ulang (logic of repetition) tidak terjadi dan untuk mengedepankan logika temuan baru (logic of discovery) idealnya tindak lanjut dari ketiga rumusan di atas lebih menekankan dan mengacu pada berbagai interkoneksi-interrelasi fenomena sosial ekonomi politik dan hukum yang terus berproses. Oleh karena itu, dalam tulisan ini perkembangan hukum Islam khususnya hukum ekonomi syariah di Indonesia dipetakan ke dalam empat era konseptual paradigmatik yang merepresentasikan perjalanan panjang dan progresifitas hukum ekonomi syariah mulai awal hingga saat ini, yaitu era syariah, fiqh, qânûn, dan qadla.

\section{Hukum Ekonomi Syariah di Era Syariah}

Istilah syariah berasal dari bahasa Arab "syara'a, yasyra'u, syari'atan" yang artinya aturan atau ketentuan. Ada beberapa ciri khas era syariah. Pertama, berlangsung di era Rasulullah Saw dan Sahabat, sebagaian dari era syariah sempat ditunggui oleh Rasulullah Saw dan sebagian yang lain sudah ditinggal wafat Rasulullah Saw. Kedua, wilayah Islam bersifat regional, masih di seputar Makkah dan Madinah. Kuantitas umat Islam didominasi suku-suku di Arab, seperti suku Quraisy dan suku Badui. Ketiga, sumber hukum Islam alQuran dan hadis serta langsung implementatif karena mayoritas umat Islam memahami bahasa al-Quran. Setiap persoalan yang muncul bisa seketika ada solusi konkritnya. Formula atau bentuk hukum ekonomi syariah di era syariah berupa prinsip-prinsip moral etis yang terkandung di dalam teks-teks al-Quran dan hadis. Beberapa literatur di Indonesia secara khusus memuat kompilasi teks-teks hukum ekonomi syariah. Jurusan Hukum Bisnis Syariah (HBS) Fakultas Syariah UIN Maulana Malik Ibrahim Malang menyusun kompilasi 40 ayat dan 40 hadis hukum

${ }^{10}$ M. Atha Mudzhar, Membaca Gelombang Ijtihad: antara Tradisi dan Liberasi (Yogyakarta: Titian Ilahi Press, 1998), h. 91 ekonomi syariah yang wajib dihafal oleh mahasiswa jurusan HBS sebagai syarat mendaftar ujian skripsi. Ilfi Nurdiana, dosen Fakultas Ekonomi UIN Maulana Malik Ibrahim Malang menulis buku Hadis-hadis Ekonomi yang memuat dan mendeskripsikan ayat-ayat ekonomi dan diterbitkan oleh UINMalang Press. Mardani menulis buku Ayat-ayat dan Hadis Ekonomi Syariah yang cukup dokumentatif dan informatif serta diterbitkan oleh PT. Rajawali Pers.

\section{Hukum Ekonomi Syariah di Era Fiqh}

Ada beberapa ciri khas era fiqih. Pertama, berlangsung di era tabi'in, tabiit tabiin, sampai lahirnya majâlât al-ahkâm al-adliyah di era Turki Utsmani (1868 M). Kedua, wilayah Islam mulai menyebar di sekitar kawasan Timur Tengah (multinasional). Ketiga, sumber utama hukum Islam tetap al-Quran dan hadis. Pada era ini muncul dan berkembang pesat penafsiran para Mujtahid terhadap al-Quran dan hadis sebagai kegiatan ijtihad (interpretasi/tafsir) dari para fuqaha. Sehingga muncul berbagai kitab fiqh, mulai fiqh Maliki, fiqh Hanafi, fiqh Syafii, fiqh, Hanbali, dan fiqh-fiqh yang lain. Keempat, di era fiqh berkembang pesat kajian teoritis paradigmatik. Di antaranya adalah diskusi hangat oleh berbagai pihak untuk merumuskan definisi hukum ekonomi syariah.

Ekonomi Syariah adalah semua kegiatan ekonomi baik yang telah dikenal dan sedang dijalankan saat ini atau yang akan ditemukan kemudian yang tidak menimbulkan kerugian (mudharat) pada orang lain dan tidak melibatkan barang, hal, dan jasa yang diharamkan oleh Islam. Ekonomi Syariah adalah kegiatan ekonomi yang berlandaskan aturan dan etika Syariah Islam. ${ }^{11}$ Menurut Abdul Mannan, ekonomi syariah adalah ilmu pengetahuan sosial yang mempelajari masalahmasalah ekonomi rakyat yang diilhami oleh nilai-nilai islam. ${ }^{12}$

Hasanuzzaman mendefinisikan ekonomi syariah sebagai pengetahuan dan aplikasi dari

\footnotetext{
${ }^{11}$ Ekonomi Syariah. aza.blog.friendster.com/2007/02/ekonomi-syariah/, diunduh 6 Desember 2014

${ }^{12}$ Muhammad Abdul Mannan, Teori dan Praktek Ekonomi Islam, (Yogyakarta: Dana Bhakti Wakaf, 1993), h. 351
} 
anjuran dan aturan syariah yang mencegah ketidakadilan dalam memperoleh sumber daya material, sehingga tercipta kepuasan manusia dan memungkinkan mereka menjalankan perintah Allah dan masyarakat. Khursid Ahmad menambahkan, bahwa ekonomi syariah adalah usaha sistematis untuk memahami masalah ekonomi dan perilaku manusia dalam hubungannya dengan persoalan tersebut menurut perspektif Islam. ${ }^{13}$ Ekonomi Syariah lebih luas dari sekadar perbankan dan asuransi syariah. Berbagai sektor ekonomi seperti hotel, media cetak, media elektronik, retail, jasa, pasar modal, toko, warung, dan berbagai jenis perdagangan yang dikelola berlandaskan aturan dan etika syariah, keseluruhannya termasuk ke dalam bingkai ekonomi Syariah.

Definisi paling populer menurut Dawam Rahardjo, ekonomi adalah segala aktivitas yang berkaitan dengan produksi dan distribusi di antara orang-orang. Ilmu ekonomi syariah adalah ilmu yang mempelajari prilaku manusia sebagai hubungan antara tujuan dan alat-alat langka yang mengandung pilihan dalam penggunaannya sesuai syariat Islam. ${ }^{14}$

Selain perdebatan seputar definisi ekonomi syariah sebagai bagaian dari hukum ekonomi syariah, di era fiqh juga berkembang rumusan penting terkait deskripsi ekonomi syariah. Ekonomi syariah bertujuan untuk membantu manusia mencapai kemenangan di dunia dan di akhirat. Prinsip-prinsip ekonomi syariah mencakup: (1) Berbagai sumber daya titipan Allah swt kepada manusia; (2) Islam mengakui pemilikan pribadi dalam batas-batas tertentu; (3) Kekuatan penggerak utama ekonomi syariah adalah kerja sama; (4) Ekonomi syariah menolak terjadinya akumulasi kekayaan yang dikuasai oleh segelintir orang saja; (5) Ekonomi Islam menjamin pemilikan masyarakat dan penggunaannya direncanakan untuk kepentingan banyak orang; (6) Muslim harus takut kepada Allah swt dan hari penentuan di akhirat nanti; (7) Zakat harus dibayarkan atas kekayaan yang telah memenuhi

13 Umar Chapra, Masa Depan Ekonomi, Sebuah Tinjauan Islam, (Jakarta: Gema Insani Press, 2001), h. 121

14 Dawam Rahardjo, "Pengertian Ekonomi Islam", dalam Republika, 1 Mei 1993 batas (nisab); dan (8) Islam melarang riba dalam segala bentuk. ${ }^{15}$

\section{Hukum Ekonomi Syariah di Era Qânûn}

Uraian terkait hukum ekonomi syariah di era qânûn terdiri atas tiga tema, yaitu konstruksi norma hukum ekonomi syariah, ruang lingkup ekonomi syariah, dan posisi keilmuan hukum ekonomi Syariah.

Pertama, Konstruksi Norma Hukum Ekonomi Syariah. Ada beberapa ciri khas era qânûn. Pertama, berlangsung mulai lahirnya Majalat al-ahkam al-adliyah (1868 M) sampai awal abad 21. Kedua, diperuntukkan bagi wilayah Islam yang sudah meluas ke seluruh dunia (internasional). Ketiga, sumber hukum Islam tetap al-Quran dan hadis. Keempat, ijtihad (interpretasi/tafsir) fuqaha berkembang pesat, dan partisipasi politik pemerintahan suatu Negara makin marak. Era qânûn ditandai oleh kemunculan ketentuan hukum ekonomi syariah dalam peraturan perundang-undangan negara, mulai secara laten sampai manifest.

Ketentuan hukum ekonomi syariah muncul pertama kali di Indonesia ketika pemerintah meluncurkan kebijakan Paket Oktober 1988 yang membolehkan setiap bank menetapkan besar bunga meskipun nol persen. Pada saat itu Bank Syariah mulai berdiri. ${ }^{16}$ Pengaturan perbankan syariah selanjutnya termuat dalam UU No. 7 tahun 1992 tentang Perbankan, PP No. 72 tahun 1992 tentang Bank Bagi Hasil, dan UU No. 10 tahun 1998 tentang Perubahan UU No. 7 tahun 1992 tentang Perbankan. Pengaturan Perbankan Syariah dalam perundangan-undangan tersebut tidak dilengkapi dengan pengaturan tentang penyelesaian sengketa antara bank syariah dan nasabah. Hal ini memunculkan beragam penafsiran hukum untuk menyelesaikan sengketa ekonomi syariah.

Menurut Muhammad Syafii Antonio, jika muncul sengketa antara Bank Syariah dan nasabah, maka kedua belah pihak tidak menyelesaikan di Pengadilan Negeri tidak pula

\footnotetext{
${ }^{15} \mathrm{http}: / /$ islampeace.clubdiscussion.net/ekonomiislam-f8/pengertian-tujuan-prinsip-prinsip-ekonomi-

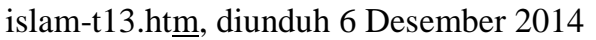

${ }^{16}$ Karnaen Perwataatmadja dan M. Syafi'i Antonio, Apa dan Bagaimana Bank Islam (Yogyakarta: Yayasan Dana Bhakti Wakaf, 1992), h. 58 dan Muh. Zuhri, Riba dalam al-Qur'an dan Masalah Perbankan (Jakarta: Raja Grafindo Persada 1996), h. 12
} 
di Pengadilan Agama, tetapi sesuai tata cara dan hukum materi syariah, yaitu lewat Badan Arbitrase Syariah Nasional (Basyarnas) yang telah didirikan oleh Majelis Ulama Indonesia (MUI) bekerjasama dengan Kejaksaan Agung RI. ${ }^{17}$ Di sisi lain, Sutan Remy Syahdeini berpandangan, bahwa di dalam tata hukum Indonesia, hukum Islam bukan merupakan hukum positif (bukan hukum yang berlaku resmi dan dapat dipaksakan atas pelanggarannya oleh pengadilan). Oleh karena itu, sengketa yang timbul antara bank syariah dan nasabah tidak diberlakukan hukum Islam. Namun, yang diberlakukan adalah hukum perjanjian sebagaimana diatur dalam $\mathrm{KUH}$ Perdata, karena KUH Perdata yang merupakan hukum positif. ${ }^{18}$

Ketidakjelasan penyelesaian sengketa ekonomi syariah akhirnya memperoleh respon dengan terbitnya UU No. 3 Tahun 2006 Tentang Peradilan Agama. Dalam Pasal 49 UU No. 3 Tahun 2006 disebutkan "Pengadilan agama bertugas dan berwenang memeriksa, memutus, dan menyelesaikan perkara di tingkat pertama antara orang-orang yang beragama Islam di bidang: (a) perkawinan; (b) waris; (c) wasiat; (d) hibah; (e) wakaf; (f) zakat; (g) infaq; (h) shadaqah; dan (i) ekonomi syari'ah."

Pasal 49 UU No. 3 Tahun 2006 di atas dengan tegas menetapkan bahwa sengketa ekonomi syariah diselesaikan oleh Peradilan Agama. Ketentuan ini semakin kuat dengan keluarnya UU No. 21 Tahun 2008 tentang Perbankan Syariah. Pasal 55 ayat (1) UU No. 21 Tahun 2008 menyebutkan "Penyelesaian sengketa Perbankan Syariah dilakukan oleh pengadilan dalam lingkungan Peradilan Agama." Kewenangan Peradilan Agama semakin lengkap dengan terbitnya UU No. 50 Tahun 2009 Tentang Perubahan Kedua atas UU Nomor 7 Tahun 1989 Tentang Peradilan Agama. Penjelasan Pasal 3A ayat (1) UU No 50 Th 2009 Tentang Perubahan Kedua Atas UU No. 7 Th 1989 Tentang Peradilan Agama disebutkan bahwa "Yang dimaksud dengan "diadakan pengkhususan pengadilan" adalah adanya diferensiasi/ spesialisasi di lingkungan peradilan agama dimana dapat dibentuk

\footnotetext{
${ }^{17}$ Antonio, Bank Syariah,..., h. 30 dan 214

18 Sutan Remi Syahdeini, Perbankan Islam dan Kedudukannya dalam Tata Hukum Perbankan Indonesia ( Jakarta: Pustaka Utama Grafiti, 1999), h. 134
}

pengadilan khusus, misalnya pengadilan arbitrase syariah, sedangkan yang dimaksud dengan "yang diatur dengan undang-undang" adalah susunan, kekuasaan, dan hukum acaranya.

Sebagai tindak lanjut amanat perundanganundangan ekonomi syariah di atas, diperlukan pembaharuan hukum formil dan hukum materiil ekonomi syariah. Sejauh ini, ada dua acuan hukum materiil ekonomi syariah, yaitu Fatwa Dewan Syariah Nasional (FDSN) dan Peraturan Mahkamah Agung (Perma) Nomor 02 Tahun 2008 tentang Kompilasi Hukum Ekonomi Syariah (KHES). Lawrence M. Friedman merumuskan bahwa suatu pembaharuan hukum tidak akan mendapatkan hukum yang efektif jika tidak didukung tiga hal, yaitu substansi hukum yang bagus, lembaga hukum yang berwibawa, dan budaya hukum yang cooperatif. ${ }^{19}$ Dalam konteks ini, fatwa DSN MUI dan KHES mengisi kekosongan substansi norma hukum di bidang hukum materiil ekonomi syariah.

Selama 2007 dan 2008 ada 4 kasus sengketa ekonomi syariah yang masuk ke Pengadilan Agama, ${ }^{20}$ dan 14 kasus sengketa ditangani Badan Arbitrase Syariah Nasional (Basyarnas). ${ }^{21}$ Sampai Juni 2007, Dewan Syariah Nasional (DSN) MUI telah menerbitkan 61 fatwa ekonomi syariah. Jika sebelum Mei 2007 fatwa DSN MUI selalu mencantumkan klausul, jika terjadi sengketa agar diselesaikan di Badan Arbitrase Syariah Nasional (Basyarnas). Maka sejak Juni 2007 DSN MUI membuat klausul baru bahwa Jika terjadi sengketa, agar diselesaikan di Badan Arbitrase Syariah Nasional (Basyarnas) atau Peradilan Agama (PA). Perubahan itu tak lepas dari disahkannya UU No. 3 Tahun 2006 tentang Peradilan Agama sebagai pengganti UU No. 7 Tahun 1989. Pasal 49 UU tersebut

19 Lawrence M. Friedman, The Legal System, A Social Sentence Perspektif (New York: Rusell Sage Foundation, 1975), h. 168-193

20 Mahkamah Agung Ditjen Badilag, Profil Peradilan Agama (Jakarta: 2008), h. 14

${ }^{21}$ Fatwa Baru DSN-MUI Perkuat Kompetensi Peradilan Agama. http:// www. Hukum online. com/berita/ baca/ hol17024/ fatwa-baru- dsnmuiperkuat- kompetensi- peradilan-agama. Diunduh 8 Desember 2014 
112 | de Jure, Jurnal Syariah dan Hukum, Volume 6 Nomor 2, Desember 2014, hlm. 107-116

memberi kompetensi kepada PA untuk menyelesaikan sengketa ekonomi syariah. ${ }^{22}$

Kedua, Ruang Lingkup Ekonomi Syariah. Menurut penjelasan Pasal 49 Huruf (i) UU No. 3 Tahun 2006, yang dimaksud dengan "ekonomi syari'ah" adalah perbuatan atau kegiatan usaha yang dilaksanakan menurut prinsip syari'ah, antara lain meliputi (a) bank syari'ah; (b) lembaga keuangan mikro syari'ah; (c) asuransi syari'ah; (d) reasuransi syari'ah; (e) reksadana syari'ah; (f) obligasi syari'ah dan surat berharga berjangka menengah syari'ah; (g) sekuritas syari'ah; (h) pembiayaan syari'ah; (i) pegadaian syari'ah; (j) dana pensiun lembaga keuangan syari'ah; dan (k) bisnis syari'ah.

Asuransi syariah adalah asuransi yang dijalankan berdasarkan prinsip takaful, yaitu suatu skema kerjasama yang dilandasi oleh nilai-nilai ukhuwah, solidaritas, saling membantu untuk memberikan bantuan finansial kepada peserta takaful jika membutuhkannya dan mereka sepakat untuk memberikan konstribusi untuk tercapainya tujuan tersebut. Konsep dasar takaful adalah saling bertanggung jawab, saling bekerjasama dan membantu, dan saling melindungi.

Reasuransi syariah adalah mengasuransikan risiko sebuah perusahaan asuransi syariah. Reasuransi syariah adalah bisnis mengasuransikan perusahaan asuransi dari kejadiaan kerugian atas proses operasional bisnis asuransi berdasar prinsip syariah. Reksadana syariah adalah wadah yang dipergunakan untuk menghimpun dana dari masyarakat pemodal sebagai pemilik harta (shabib al-mal/rabb al-mal) untuk selanjutnya diinvestasikan dalam Portofolio Efek oleh Manajer Investasi sebagai wakil shahib al-mal menurut ketentuan dan prinsip Syariah islam.

Obligasi syariah (sukuk) adalah suatu surat berharga jangka panjang berdasarkan prinsip syariah yang dikeluarkan emiten kepada pemegang obligasi syari'ah yang mewajibkan emiten membayar pendapatan kepada pemegang obligasi syari'ah berupa bagi hasil(margin/fee), serta membayar kembali dana obligasi pada saat jatuh tempo.

Dana Pensiun Lembaga Keuangan Syariah adalah dana pensiun yang diperoleh seseorang

\footnotetext{
${ }^{22}$ Fatwa Baru DSN-MUI ,,,, 8 Desember 2014
}

setelah purna tugas yang diberikan oleh instansi atau perusahaan tempat bekerja yang dititipkan di Lembaga Keuangan Syariah dengan prinsip (a) penghematan pajak atas iuran peserta, (b) prinsip penghematan pajak atas hasil investasi. Hasil investasi dana pensiun dalam bidang penanaman modal tertentu memperoleh fasilitas penundaan pajak penghasilan, (c) prinsip keamanan dana dari segala macam sitaan (creditor proof). Sampai sejauh ini baru ada satu DPLK Syari'ah yaitu Dana Pensiun Lembaga Keuangan Bank Muamalat atau DPLK Muamalat.

Sejak tahun 1990 sampai tahun 2010, perkembangan ekonomi syariah di Indonesia merambah berbagai sektor. Sampai Juli 2008, di Indonesia ada 287 Lembaga Keuangan Syariah (LKS) dalam berbagai jenis. Menurut data Bank Indonesia, sampai Mei 2005, jumlah nasabah/deposan perbankan syariah lebih dari 2 juta orang. Sedangkan jumlah nasabah pembiayaan sekitar 300.000-an orang. Data itu belum termasuk nasabah asuransi, pegadaian, pasar modal, dan dana pensiun syariah. Juga belum termasuk nasabah Baitul Mal wat Tamwil (BMT) yang mencapai lebih dari 3 juta orang.

Tabel 1:

Jumlah Lembaga Keuangan Syariah (LKS) di Indonesia sampai Juli $2008^{23}$

\begin{tabular}{|l|c|}
\hline $\begin{array}{l}\text { LEMBAGA KEUANGAN } \\
\text { SYARIAH }\end{array}$ & JUMLAH \\
\hline Bank Umum Syariah & 4 \\
\hline $\begin{array}{l}\text { Unit Usaha Syariah Bank } \\
\text { Umum }\end{array}$ & 14 \\
\hline Unit Usaha Syariah BPD & 15 \\
\hline Bank Kustodian Syariah & 6 \\
\hline BPR Syariah & 117 \\
\hline Asuransi Syariah & 42 \\
\hline Reasuransi Syariah & 3 \\
\hline $\begin{array}{l}\text { Broker Asuransi dan } \\
\text { Reasuransi }\end{array}$ & 6 \\
\hline Reksa Dana Syariah & 22 \\
\hline $\begin{array}{l}\text { Obligasi Syariah \& Medium } \\
\text { Term Notes (MTN) }\end{array}$ & 38 \\
\hline Pembiayaan Syariah & 11 \\
\hline Pegadaian Syariah & 1 \\
\hline
\end{tabular}

\footnotetext{
${ }^{23} \mathrm{http} / / /$ www.mui.or.id/mui_in/product_2/lks_lbs.php ?id=66, diunduh 8 Desember 2014
} 
Mohamad Nur Yasin, Progresifitas Formulasi Hukum Ekonomi...| 113

\begin{tabular}{|l|c|}
\hline DPLK Syariah & 2 \\
\hline Bisnis Syariah & 4 \\
\hline Modal Ventura Syariah & 2 \\
\hline $\begin{array}{l}\text { Lembaga Penjaminan } \\
\text { Syariah }\end{array}$ & 1 \\
\hline \multicolumn{1}{|c|}{ JUMLAH } & 287 \\
\hline
\end{tabular}

Pesatnya perkembangan ekonomi syariah tidak lepas dari politik hukum nasional. Tidak berbeda dengan yang lain, tanpa kekuatan politik tidak ada sistem ekonomi yang mapan. Ekonomi kapitalis bisa kuat karena dukungan politik Amerika, ekonomi sosialis pernah mapan karena dukungan Uni Sovyet, ekonomi terpimpin pernah jaya karena dukungan Pemerintah Orde Lama, dan ekonomi Pancasila pernah sangat populer karena dukungan Pemerintah Orde Baru. ${ }^{24}$

Ketiga, Ekonomi Syariah dalam Struktur Keilmuan Islam. Untuk mengetahui kesejatian ekonomi syariah, diperlukan pemetaan konsep terkait dengan posisi sektor ekonomi syariah dalam struktur keilmuan Islam. Skema berikut ini diharapkan membantu pemahaman peta konsep ekonomi syariah. ${ }^{25}$

Dalam bingkai keilmuan Islam, banyak kajian hukum ekonomi Islam yang muncul di era qânûn terutama setelah era 2000-an. Hampir setiap buku yang terbit di era setelah 2000-an mengacu pada data-data empirik dan praktek hukum ekonomi syariah. Di sini menunjukan bahwa implementasi hukum ekonomi syariah semakin tak terbendung di mana saja dan kapan saja. Saat ini hukum ekonomi Islam telah menjadi salah satu indikator utama (disamping ilmu pengetahuan teknologi dan syiar Islam) bagi menguatnya peradaban Islam secara global. Dengan hukum ekonomi syariah Islam bisa masuk ke jantung yang paling dalam bumi Eropa dan Amerika tanpa ada kecurigaan sedikitpun atau sikapsikap pejoratif yang menghadangnya.

\footnotetext{
24 M. Nur Yasin, Hukum Ekonomi Islam (Malang: UIN Malang Press, 2009), h. 2

25 Mustafa Ahmad Zarqa, Al-Fiqh al-Islami fi Tsaubih al-Jadid, al-Madkhal al-Fiqh al-Am (Damaskus: Matba' Jamiah al-Dimasqy, 1959), h. 6. Lihat juga, Muhammad Syafii Antonio, Bank Syariah, Bagi Bankir dan Praktisi Keuangan (Jakarta: Bank Indonesia dan Tazkiyah Institute, 1999), h. 5
}

\section{Hukum Ekonomi Syariah di Era Qadla}

Ada beberapa ciri khas era qadla. Pertama, berlangsung mulai awal abad 21 dan seterusnya. Kedua, peradaban Islam sudah membumi di seluruh pelosok dunia (internasionality). Ketiga, sumber hukum tetap al-Quran dan hadis sekaligus berkembang suasana ijtihad (interpretasi/ tafsir) fuqaha yang terus berproses, partisipasi politik pemerintahan suatu negara semakin intensif, dan dengan berbagai referensi hukum yang ada. Keempat, tuntutan penyelesaian sengketa ekonomi syariah secara cepat dan akurat. Kelima, hakim dituntut untuk semakin produktif, kreatif, dan inovatif memproduk hukum ekonomi syariah baik dengan mengacu pada peraturan perundangan-undangan ekonomi syariah maupun dengan cara menggali nilai-nilai keadilan yang hidup di tengah masyarakat. Karena, para hakim bukan hanya menjadi juru bicara perundangan-undangan (speakers of law), tetapi melalui ijtihad dan putusan-putusan yang dibuat para hakim juga berstatus sebagai juru bicara keadilan (speakers of justice).

Menurut Lawrence M. Friedman, hukum memiliki empat fungsi. Fungsi pertama adalah dispute settlement (penyelesaian sengketa). Menurut Richard L. Abel, sengketa adalah pernyataan publik mengenai tuntutan yang tidak selaras (inconsistent claim) terhadap sesuatu yang bernilai. $^{26}$ Dalam kerangka berpikir ushul fiqh, konsep Friedman memiliki semangat yang sama dengan diktum ushuliyyin hukmul hakim yarfa'ul ikhtilafi (keputusan hakim menghilangkan dan menyelesaikan persengketaan).

\section{Asas-asas Progresif Hukum Ekonomi Syariah}

Munculnya beragam tipologi formulasi hukum ekonomi syariah di atas tak lepas dari adanya tarik ulur metode dan disain pola pikir masyarakat Muslim dalam mempersepsi eksistensi hukum ekonomi syariah. Noul J. Coulson menawarkan enam konsep pasangan pilihan asas yang dapat mempengaruhi

${ }^{26}$ Lawrence M. Friedman, The Legal System, A Social Sentence Perspektif (New York: Rusell Sage Foundation, 1975), h. 15 
masyarakat Muslim terhadap hukum Islam, termasuk hukum ekonomi syariah.

Pertama, Unity dan diversity. Satu sisi hukum ekonomi syariah memiliki karakter satu macam (unity) sebagai kesatuan. Artinya hukum ekonomi syariah adalah hukum Tuhan. Seharusnya hukum ekonomi syariah satu macam saja untuk seluruh umat Islam bahkan untuk seluruh umat manusia. Di sisi lain, hukum ekonomi syariah juga memiliki karakter beragam (diversity). Artinya, hukum Islam harus bermacam-macam, sebagaimana ragamnya nalar manusia dan ragamnya mazhab-mazhab hukum dalam Islam.

Kedua, authoritarianism dan liberalism. Satu sisi, hukum ekonomi syariah memiliki karakter memaksa (authoritarianism) atau otoriter. Artinya, hukum ekonomi syariah mengikat dan memaksa bahkan dogmatis dan doktriner kepada seluruh umat Islam di mana ideal. Artinya, hukum ekonomi syariah dirumuskan oleh para teoritisi dan lebih banyak mengekspresikan hal-hal yang ideal dan maksimal. Di sisi lain, hukum ekonomi syariah sebagai hukum yang realistis, yakni perumusan hukum ekonomi syariah berdasarkan kondisi riil yang ada di tengah masyarakat, sehingga merupakan ekspresi masyarakat umum sebagai pelaku ekonomi dan bukan sekadar ekspresi terbatas dari para elit agama saja.

Keempat, stability dan chance. Hukum ekonomi syariah adalah hukum yang permanen (stability). Artinya, hukum ekonomi syariah itu satu, mengikat dan ideal maka tidak boleh berganti-ganti dan tidak memerlukan revisi atau inovasi dari pikiran manusia. Di sisi lain, hukum ekonomi syariah memiliki karakter berubah-ubah. Artinya, karena hukum ekonomi syariah itu beragam, beba, dan realistis, maka hukum ekonomi syariah harus berubah-ubah.

\section{EKONOMI SYARIAH DALAM STRUKTUR KEILMUAN ISLAM}

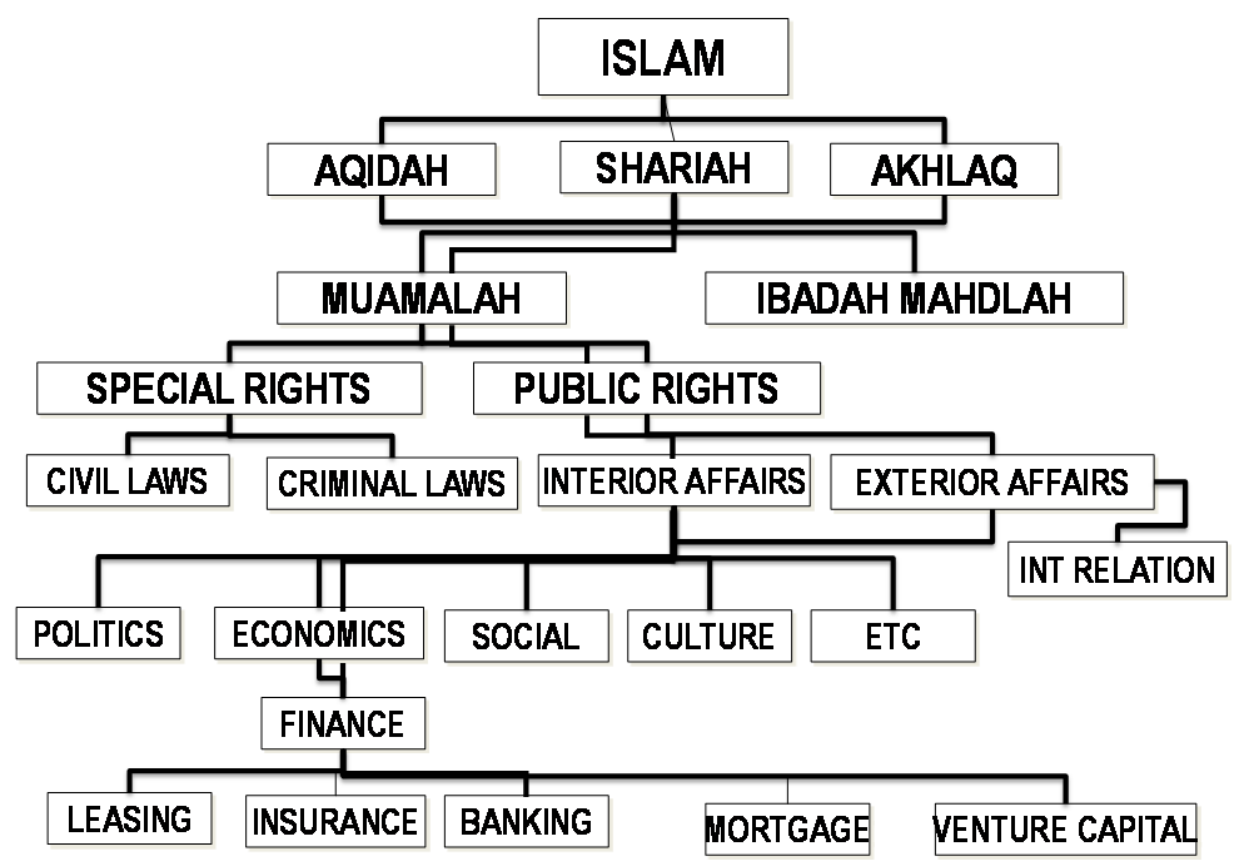

dan kapan saja berada. Setiap perjanjian yang dibuat mengikat kepada para pihak dan tidak ada pilihan lain kecuali mentaati perjanjian tersebut. Di sisi lain, hukum ekonomi syariah memiliki karakter yang bebas (liberal). Artinya, hukum ekonomi syariah menganut asas bebas. Penerapan hukum ekonomi syariah sangat akomodatif terhadap situasi dan kondisi yang mengitari pelakunya.

Ketiga, idealism dan realism. Satu sisi, hukum ekonomi syariah memiliki karakter
Hukum ekonomi syariah memerlukan partisipasi dan kontribusi akal manusia agar bisa membumi dan menyejarah dalam kehidupan manusia. ${ }^{27}$

Untuk terwujudnya suatu masyarakat yang perilaku hukum sosial keagamaannya tumbuh ke arah yang lebih positif, ada

\footnotetext{
${ }^{27}$ Noul J. Coulson, Conflicts and Tension in Islamic Yurisprudence (Chicago and London: The Universiy of Chicago Press), h. 20-116
} 
Mohamad Nur Yasin, Progresifitas Formulasi Hukum Ekonomi...| 115

kepastian dan pertanggung-jawaban hukum, menurut Atho Mudhar, diperlukan tiga syarat. Pertama, adanya tingkat pendidikan dan tingkat keterbukaan yang tinggi dari masyarakat Muslim. Kedua, adanya keberanian di kalangan umat Islam untuk mengambil pilihan-pilihan yang tidak konvensional dari pasangan-pasangan pilihan sebagaimana ditawarkan Noul J. Coulson di atas. Ketiga, memahami faktor sosio-kultural yang melatarbelakangi lahirnya dan memotivasi lahirnya suatu produk hukum Islam, agar dapat memahami partikularisme dan semangat terdalam dari produk pemikiran hukum Islam tersebut. $^{28}$

Dengan memahami latar belakang sosial ekonomi politik setiap produk hukum ekonomi syariah sebagai bagian penting dari hukum Islam dapat diperoleh berbagai kearifan intelektual yang memperkaya potensi-potensi dan keunggulan lokal (local wisdom) yang menjadi sumber hukum materiil untuk kemudian menginspirasi lahirnya berbagai sumber hukum formil.

\section{Kesimpulan}

Kini di akhir tahun 2014, jika menggunakan standar pakto 1988 berarti hukum ekonomi syariah di Indonesia telah berumur 26 tahun. Jika dimulai tahun 1992 ketika Bank Muamalah Indonesia (BMI) berdiri kini hukum ekonomi syariah berumur 22 tahun. Jika diukur dari UU No. 3 Tahun 2006 berati hukum ekonomi syariah berumur 8 tahun. Jika standarnya UU No. 21 Tahun 2008 tentang Perbankan Syariah berarti hukum ekonomi syariah berumur 6 tahun. Umur 6 tahun dalam kehidupan manusia adalah saat-saat di mana seseorang sedang duduk di kelas 1 Madrasah Ibtidaiyah atau Sekolah Dasar, saat di mana seseorang belum sampai pada umur bâligh, relatif mendahulukan untuk bermain dari pada belajar, belum memiliki kecakapan hukum (ahliyatul ada') untuk melakukan perbuatan hukum, dan masih di bawah pengampuan wali atau orang tua. Jika dianalogikan dengan anak yang berumur 6 tahun berarti hukum ekonomi syariah di Indonesia masih berada pada situasi

\footnotetext{
${ }^{28}$ M. Atho Muzdhar, "Fiqh dan Reaktualisasi Ajaran Islam", dalam Budhy Munawar Rahman, Kontekstual;isasi Doktrin Islam dalam Sejarah (Jakarta: Paramadina, 1995), h. 376
}

yang terus menerus memerlukan penyempurnaan dan pengembangan. Dalam kondisi yang demikian wajar jika muncul statemen bahwa dalam prakteknya ekonomi syariah tidak ada, yang ada adalah ekonomi menuju syariah. Meskipun demikian, apapun kondisi dan situasi hukum ekonomi syariah yang ada sekarang tetap harus disyukuri. Dibanding yang lalu saat ini jauh lebih konstruktif dan kondusif. Dalam hal ini berlaku asas hukum "apa saja yang belum bisa diperoleh/dicapai secara keseluruhan janganlah ditinggal keseluruhan (ma lam yudrak kulluhu lam tutrak kulluhu). Dengan demikian, agendaagenda reformasi, restorasi, dan revolusi di bidang hukum ekonomi syariah harus terus berjalan sambil disempurnakan di tengah perjalanan, baik pada aspek teori maupun implementasi. Fase-fase konseptual paradigmatik yang ada pun bisa dikembangkan lebih lanjut. Siapa saja yang hari esuk lebih baik dari hari ini maka dialah orang-orang yang beruntung dan akan menggenggam peradaban, semoga. 
116 | de Jure, Jurnal Syariah dan Hukum, Volume 6 Nomor 2, Desember 2014, hlm. 107-116

\section{DAFTAR PUSTAKA}

Afzalurrahman, Muhammad Sebagai Seorang Pedagang. Jakarta. Yayasan Swarna Bhumi, 1997

Antonio, Muhammad Syafii. Bank Syariah, Bagi Bankir dan Praktisi Keuangan. Jakarta. Bank Indonesia dan Tazkiyah Institute, 1999

Bek, Muhammad Khudari. Tarikh Tasyri alIslami. Beirut. Darul Fikr, 1988

Chapra, Umar. Masa Depan Ekonomi, Sebuah Tinjauan Islam. Jakarta. Gema Insani Press, 2001

Coulson, Noul J. Conflicts and Tension in Islamic Yurisprudence. Chicago and London. The Universiy of Chicago Press

Ekonomi Syariah, http://qoulaza.blog.friendster.com/2007/02/ekonomi -syariah/, diunduh 8 Desember 2014

Fatwa Baru DSN-MUI Perkuat Kompetensi Peradilan Agama. http:// www. Hukum online. com/berita/ baca/ hol17024/ fatwa-baru- dsnmui-perkuat- kompetensiperadilan-agama. Diunduh 8 Desember 2014

Friedman, Lawrence M. The Legal System, A Social Sentence Perspektif. New York. Rusell Sage Foundation, 1975

Geertz, Clifford. The Interpretation of Cultures. New York. Basic Book, Inc., 1973

http://islampeace.clubdiscussion.net/ekonomiislam-f8/pengertian-tujuan-prinsipprinsip-ekonomi-islam-t13.htm, diunduh 8 Desember 2014

http://www.mui.or.id/mui_in/product_2/lks_lbs .php?id=66

India Cari Solusi Penyaluran Produk Keuangan Syariah, Republika on line, 8 April 2010 . http://www.republika.co.id/berita/bisnissyariah/berita/ 10/04/ 08/ 110177-indiacari-solusi-penyaluran-produk-keuangan- syariah, diunduh 8 Desember 2014

Ka'bah, Rifyal. Hukum Islam di Indonesia, Perspektif Muhammadiyah dan NU. Jakarta. Universitas Yarsi Press, 1999

Lacey, Terry. Growth of Islamic Banking and Finance in the United Kingdom, http://mifsifeui.wordpress.com/category/ ekonomi-islam, diunduh 8 Desember 2014.

Mahkamah Agung Ditjen Badilag, Profil Peradilan Agama. Jakarta. 2008

Mannan, Muhammad Abdul. Teori dan Praktek Ekonomi Islam. Yogyakarta. Dana Bhakti Wakaf, 1993

Mudzhar, M. Atha. Membaca Gelombang Ijtihad: antara Tradisi dan Liberasi. Yogyakarta. Titian Ilahi Press, 1998

Mustafa Ahmad Al-Fiqh al-Islami fi Tsaubih al-Jadid, al-Madkhal al-Fiqh al-Am. Damaskus. Matba' Jamiah al-Dimasqy, 1959

Muzdhar, M. Atho. "Fiqh dan Reaktualisasi Ajaran Islam”, dalam Budhy Munawar Rahman. Kontekstualisasi Doktrin Islam dalam Sejarah. Jakarta. Paramadina, 1995

Perwataatmadja, Karnaen dan M. Syafi'i Antonio, Apa dan Bagaimana Bank Islam. Yogyakarta. Yayasan Dana Bhakti Wakaf, 1992

Rahardjo, Dawam."Pengertian Ekonomi Islam", dalam Republika, 1 Mei 1993

Syahdeini, Sutan Remi. Perbankan Islam dan Kedudukannya dalam Tata Hukum Perbankan Indonesia. Jakarta. Pustaka Utama Grafiti, 1999

Syalthout, Mahmud. al-Islam, Aqidah wa Syari'ah. Kairo. Darul Qalam, 1966

Yasin, M. Nur. Hukum Ekonomi Islam. Malang. UIN Malang Press, 2009

Zuhri, Muh. Riba dalam al-Qur'an dan Masalah Perbankan. Jakarta. Raja Grafindo Persada, 1996 